\title{
Food Resilience in Timor Tengah Selatan Regency, East Nusa Tenggara Province-Indonesia
}

\author{
Nursalam $^{1 *} \quad$ Jacob Wadu $^{2} \quad$ Melkisedek N.B.C.Neolaka ${ }^{3}$ \\ 1,2,3, Department of Public Administration, University of Nusa Cendana, \\ Kupang- Indonesia (85001) \\ * E-mail of the corresponding author : nursalamjeppu@yahoo.com
}

\begin{abstract}
This study aims to determine the food resilience of the local communities in Timor Tengah Selatan Regency, East Nusa Tenggara Province, Indonesia. The research uses case studies related to food resilience, namely; aspects of food availability, access and utilization, as well as food stability. The study design uses the mix method approach (Creswell, 1994., Neuman, 2003) by prioritizing qualitative methods (dominant-less dominant design, Creswell: 1994). The quantitative data in the form of frequency tables and analysis of the results of their categorization forms the basis of analysis and interpretation.

The based on the research results, it shows that the food resilience in Timor Tengah Selatan regency is good category. This research recommends several things; (a) it is necessary to revitalize the rural livestock sector; (b) it is necessary to revive the local-based rural financing system; (c) it is necessary to develop risk management so that all rural communities in Timor Tengah Selatan regency have an understanding of risk factors and the ability to overcome stressful situations to the entire community and food stakeholders in this area.
\end{abstract}

Keywords: Food System, Food security, Food resilience, and Sustainable Food.

DOI: $10.7176 /$ JPID/58-05

Publication date: January $31^{\text {st }} 2021$

\section{INTRODUCTION}

The food resilience is a concept used to measure adaptability to face the level of food insecurity in an area. Resilience is adopted as a generic approach to understanding ecological-social systems. The ecological-social system is an integrated system of eco-systems and human society that is feedback, reciprocal and interdependent, this concept emphasizes the human perspective on nature (Folke et al, 2010). Based on this position, resilience is defined as the capacity of a system to survive and adapt to disruption at any time that is not predicted and calculated, (Tendall et al, 2015).

In the context of a food system, resilience can be defined as a measure of the ability of a system to remain stable and adapt to new situations without experiencing catastrophic changes in its basic function. The risk of decreased function and service provision in the food system is high when society is affected by the weakening of the public sector and the loss of market structure (Pingali, 2005).

The research results Nursalam (2019) show that the community food security system in Timor Tengah Selatan regency is not yet optimal to achieve a sustainable food security system. The community food system in Timor Tengah Selatan (TTS) regency has a high vulnerability to damage the food security patterns of the people in this area.

The Timor Tengah Selatan regency is an area in the province of East Nusa Tenggara (Indonesia) which often experiences food shortages due to insufficient agricultural food production. The following describes the food shortage data in Timor Tengah Selatan regency.

Table 1: Data on Food Shortages in TTS Regency in 2018

\begin{tabular}{|l|l|l|}
\hline No & \multicolumn{1}{|c|}{ Item } & \multicolumn{1}{|c|}{ Aggregate and percentage } \\
\hline 1 & Number of Affected Sub-Districts & $16(50 \%)$ \\
\hline 2 & Number of Villages Affected & $105(36,32 \%)$ \\
\hline 3 & Number of Family Heads & 54.292 \\
\hline 4 & number of victims ( number of victims) & 17.711 \\
\hline 5 & Damage Area & $15.882(\mathrm{Ha})$ \\
\hline 6 & heavily Affected & 57 Villages $(19,79)$ \\
\hline 7 & Light Impacted & 48 Villages $(16,61)$ \\
\hline
\end{tabular}

Source: Food Security Office of TTS Regency, 2018

In dealing with food shortages as described in table 1, strategies and coping taken by society in adapting is by way; (a) direct entitlement; (b) exchange entitlement; (c) social entitlement. Adaptation strategies are related to efforts to organize and build family food security in the long term. Whereas the coping mechanism is related to 
the short term effort to survive against extreme hunger, therefore, it is also called the coping mechanism (Ofong, 2007).

Food system resilience can be achieved by applying the following principles, namely; (a) strengthen food diversity; (b) rebuilding local institutions and traditional support networks; (c) strengthen local knowledge and; (d) building the ability of farmers to adapt and reset the food security system, Pingali (2005).

The work of mechanisms to implement the four principles that will rebuild the functioning of the food system and strengthen its resilience requires affirming the conceptual and operational framework, so that it can be adapted to the context, namely the context of the resilience system in Timor Tengah Selatan regency.

There are various approaches to assessing the resilience of a system, Ecological-social resilience, social resilience, development resilience (Quinlan. 2016). Regarding the assessment of community food resilence in TTS Regency, the authors use an ecological-social resilience approach (Carpenter et al. (2001). The ecological-social resilience approach is a resilience approach where the system can work well to absorb various disturbances without destroying system stability; the system has the capacity to learn and adapt; systems have the ability to self-regulate. The main emphasis of this resilience approach are; adaptability; learning abilities and innovation (Quinlan. 2016).

A food security system is considered to have resilience if it contains elements of sustainability, the two of them have a very strong and complementary relationship. Sustainability is emphasized as the ability to achieve goals without jeopardizing the ability of the system to achieve future goals. The food system is considered to have resilience if it has the ability to deal with disturbances at any time, conversely, a food system can be sustainable if it has the ability to sustain the system in the long term, so that sustainability is a measure of the performance of the food system

In the context of assessing the resilience of community food security systems towards food security sustainability, the authors use the Twin Track approach (FAO, 2004). The twin track approach is a conceptual and operational analysis approach, which includes two tracks, namely; (1) the rural livelihood improvement measures; (2) provide support quickly to food vurnerable groups Pingali (2005). These two pathways reinforce and interact with each other, which then results in incentives towards a stable community food security.

\section{LITERATURE REVIEW}

\section{Previous Research on Food Resilience}

(1) The research conducted by Rueter (2018), with the title: understanding food system resilience in Bali: a moral economic approach, This study provides an overview of how the food system in Indonesia and in other developing countries deals with rapid changes in production systems, trade, and consumption patterns. In Bali food resilience is formed from the central highlands and the northeast coast of Bali, Their food system relationship has long been through regional trade relations between coastal and upland communities whose food products are complementary. This study uses a moral economic approach in explaining the decline in local food security at the systemic level, and also to explore how food security can be improved.

The resilience of the food system must also become "moral economy" in terms of what has been produced means that the food system does not harm small farmers, What is meant by moral economy in this study is in line with the opinion of Halberg and Muller (2013) which states that organic agriculture has a positive influence on the livelihoods and food security of smallholder farmers. Sustainable agricultural production and community-based economic morale are two things that cannot be separated.

Paying attention to the moral dimension of the food system will make a major contribution to increasing agricultural development and food security programs. Based on the results of the study, it is concluded that economic morale greatly contributes to the decline or increase in food security and food sovereignty in "modernizing" the local food system. the use of moral economic principles implicitly or explicitly contributes to the success of community-led efforts to rebuild food systems that are ecologically and socially sustainable. The resilience of the food system is significantly influenced by the extent to which aspects of food production and exchange are supported by mutually beneficial cultural values and social practices.

An effective moral economy will provide mutual security through the sharing of risks and benefits. The moral foundations are justice, trust and cooperation between farmers and consumers. The results of this study have provided prospects for economic morale, namely, the need for reform and redesign of traditional economic morals that have the potential to provide better livelihoods for farmers and food system resilience.

2. The Folke's research (2006) with the title: Resilience: An Emergency for Perspectives for Systems Social - Ecological Analysis. This study uses a socio-ecological approach in understanding the perspective of resilience and provides an overview of its development. By using a social-ecological approach, research has succeeded in finding various interesting things in eco-persistence from the $60 \mathrm{~s}$ to the $70 \mathrm{~s}$.

The resilience approach studied emphasizes non-linear dynamic aspects, thresholds, uncertainties, and spatial scales. Data collection was carried out by observing the dynamics of the ecosystem and interpreted with a 
mathematical model. The results of this mathematical model are then developed into an adaptive management approach that can be used to respond to changes in ecosystems.

The results showed that the concept of resilience will facilitate understanding of; social processes, social learning, social memory, mental models and knowledge, systems integration, scenario views and development, leadership, agents and groups of actors, social networks, inertia and institutional and organizational change, adaptive capacity, transformability, adaptive governance systems, which enable management of ecosystem services. Some of the obstacles found were how to explain the feedback from the interrelationship between social and ecological systems, the causes of vulnerability and how to develop resilience, how the interplay between the components of ecological and social systems, the appropriate scale and the role of adaptive capacity in the context of resilience.

3. The research conducted by Tata Ngome et al (2019) with the title: Assessing household food insecurity experiences in the context of deforestation in Cameroon. The background of the view that forest area is an area of reconciliation with a strategy to stop deforestation and the concern in achieving increased supply and access to sustainable food, which is a challenge for development planners and forest managers.

The study was carried out in the forested area of Cameroon which constitutes $10 \%$ of the Congo Basin forest. An area characterized by increasing deforestation and high rates of poverty and food insecurity. The aim of the study was to understand the characteristics, prevalence and severity of household food insecurity when deforestation increases. The data collection was done by using a questionnaire that included 9 questions using the Household Food Insecurity Access Scale (HFIAS) approach which was designed to obtain information on the prevalence of food-vulnerable households.

At least one-third of households at all rates of deforestation are highly food insecure and more than half of the population suffers from moderate to severe food insecurity.The Most $(97 \%)$ of households reported experiencing scarcity of food due to lack of resources. Households in areas with a low level of deforestation are more vulnerable to food than households in areas with moderate and high deforestation rates

The based on these facts, it can be concluded that household food insecurity is exacerbated by increasing deforestation, although generally environmental conditions are favorable for food production, so food insecurity is still high.

The three studies above all aim to obtain information about the concept of resilience which is applied differently to certain objects, while the authors see more of the community's food resilience from the Twin Track approach (FAO, 2004). The twin track approach is a conceptual and operational analysis approach, which includes two tracks, namely; (1) rural livelihood improvement measures; (2) provide support quickly to food vulnerable groups.

\section{Food Security}

The food security is a perception regarding the situation of the relationship between humans and the need for food. Food is a commodity commonly eaten by humans to meet their daily needs. Until now this concept has undergone many changes, namely occurring at the global, national, household and individual levels, from the perspective of food as a basic need to the perspective of livelihood and from objective indicators to subjective perceptions (Lassa, 2009)

According to Pakpahan and Pasandaran (1990) the perception of food security will perhaps be clearer if we approach it from the opposite side, namely by imagining a food insecurity situation. The food situation in an area is vulnerable if there is a group of people in the area experiencing difficulties in obtaining basic food needs for their survival. The Food in the concept of food security needs to be defined as the staple food of a society being discussed, not all food alternatives. Staple food is different from one society to another according to differences in their respective cultures. In addition, perceptions of staple food will also vary according to income levels in the same society.

In the context of the relationship between humans and food, the form of relationship that needs to be considered in the analysis of food security is actually the relationship between humans and humans to food. The food consumed by $\mathrm{X}$ today is food that cannot be consumed by other people, and vice versa (Pakpahan and Pasandaran, 1990). Therefore food security is a product of the relationship between people and people, and not people with food.

Food security always has a social context, this is based on the fact that food security conditions need to be achieved for the following reasons; (1) the food security situation is in itself a safe situation; (2) food security is needed, especially in facing the element of uncertainty in food production in the future.

The Maltusians argue that food insecurity and hunger are a matter of production and availability alone, but this is denied by some food experts, among others, by Dreze and Sen (1989) who state that food insecurity and hunger occur due to lack of access to food.

In an economic structure where the transaction process is a medium for the flow of food flow from one party to another, food security is conditioned by the factors that determine the relationship between people and 
people through the Pakpahan and Pasandaran transaction process (1990). These factors include: (a) ownership of something, including labor or an item that can be exchanged for food; (b) natural disasters that can destroy agricultural production such as drought, floods or pest infestation; (c) political instability; (d) other changes outside the food system

Since the $80 \mathrm{~s}$, the discourse on food security has been dominated by the food entitlements, risks and vulnerabilities. According to Timmer (2005) food security exists when all people at all times have physical and economic access to sufficient food needs in life for production and health. Food security has three dimensions, namely: (a) sufficient availability of food in terms of good quality and supplied through domestic and imported production; (b) access by households and individuals to appropriate food, and; (c) food utilization through adequate food, clean water, sanitation and health care.

\section{Sustainable Food Systems}

The sustainable food system is a continuation of the concept of the food system, food security and food resilience. However, the discourse on the sustainability of a sustainable food system is separate from the concept of food security. Actually, the idea of sustainability comes from the discipline of ecology, a sustainable food system which includes social sustainability and justice between generations. Sustainable food systems require equitable access to production opportunities and inputs, as well as a balance distribution of costs, goods and services related to the use of resources. This system is also aimed at disadvantaged groups in society, with their sustainable system having the capacity to produce food for the benefit of their generations (Brklacich, Bryant, \& Smit, 1991). This system is also aimed at disadvantaged groups in society, with their sustainable system having the capacity to produce food for the benefit of their generations (Brklacich, Bryant, \& Smit, 1991).

According to Maxwell (1996: 155) and Lassa (2009: 11) there are at least four elements of sustainable food security, namely; (a) adequate food intake which is defined as the number of calories needed for an active and healthy life; (b) access to food, defined as entitlements rights to produce, buy or exchange;(c) resilience which is defined as a balance between vulnerability, risk and social security; (d) a function of time when food security can be chronic, transitional and cyclical.

According to food and nutrition security experts who are members of HLPE (High Level Panel of Experts, 2014), a sustainable food system is a food system that provides food security and nutrition for all that is based on the economy, social and environment to produce food security and nutrition for future generations and does not endanger it. This view has in common with Johnston et al (2014) arguing that there are five (5) main dimension categories of sustainable food, namely; (a) agriculture; (b) health; (c) socio-cultural; (d) environment, and; (e) socioeconomic. These dimensions are interrelated and influence each other, changes in one determining dimension will affect other dimensions and in the end will also affect food sustainability.

The American Dietetic Society (2007) also expressed its views on sustainable food systems stating that; Sustainable safeguards exist when production, processing, distribution and consumption are integrated and practices related to regeneration degrade natural resources, are socially equitable and accessible, and support community and local economic development. There are three perspectives to achieve a sustainable food system and sustainable food security, namely regarding; efficiency, barriers to demands, and changes in the food system (El Bilali, 2018)

These three perspectives reflect different conceptualizations and visions of what is desirable or practically achievable and supported by various ideologies, ethics and values. This view is not mutually exclusive but allows a combined approach to address the problem of food sustainability, integrating and utilizing all three perspectives is something that can be achieved (Garnett, 2014).

\section{Food Resilience}

The resilience and food vulnerability are two conceptual approaches that are interrelated but have different meanings in understanding how the food system and food security actors respond to change; for example when there are shocks and surprises. Resilinece is an approach, a way of thinking that provides a perspective to guide and organize thought and in a broader sense this provides a valuable context for socio-ecological systems analysis (Folke, 2006).

The based on the perspective of ecological and social theory, both explain the continuous differences in the dimensions of socio-ecological change (Miller et al, 2010). Resilience and vulnerability, are concepts related to adaptation and transformation, are the main concepts in analyzing socio-ecological change and challenges of sustainable food systems (Janssen and Ostrom, 2006)

Ther resilience is defined as the ability of a system to absorb shocks and cross a threshold into a new, possibly irreversible state so that it can regenerate after disruption (Resilience Alliance 2009). This definition can also be applied to institutional roles, social capital, leadership, and learning. The expansion of the concept of resilience, especially with regard to socio-ecological systems, produces tension between the pressure on the system, namely in the current state and the transformation to a new system condition. The way food resilience 
works can be seen when the food system responds to social conditions amid climate change. According to Adger (2000) social resilience is the ability of a group or community to cope with external pressures and disturbances as a result of social, political and environmental changes.

Meanwhile, according to Holing (2001) resilience focuses on the capacity to overcome shocks and maintain system functions, however, there are also other aspects related to the capacity to renew, reorganize, and develop. The experience so far has been that the system is less focused but trying to achieve the discourse of the system's sustainability.

Resilience as the capacity to survive in the domain of facing change, determines the persistence of relationships in a system and is a measure of the ability of this system to absorb variable changes, moving the driving variables. Ability to understand systems to support adaptation, community and economic maintenance and to respond to the way they solve problems. It is recognized that the way the system works in certain economic conditions hinders long-term development, namely in terms of sustainability and social justice (Thomas et al, 2007).

The results showed that social learning and communication processes at various institutional scales, community reorganization, and adaptive capacity were critical when resilience was developed in the lower class. Thus the resilience approach is related to how a system responds to change.

The complex systems approach that has been adopted by many resilience experts emphasizes the complexity of social, ecological, and geophysical systems, and conceptualizes them in multiple and interacting agents (Ramos and Martin, 2003). The concept of resilience adds to the understanding of the meaning of systems, interconnectedness, ecological thresholds, socio-ecological relationships, and feedback.

According to Carpenter et al (2001) interpreted social - ecological resilience as; (a) a number of disturbances that can be absorbed by a system; (b) the extent to which the system can regulate itself due to external deficiencies and disturbances, and; (c) the extent to which the system can develop and develop its capacity to learn and adapt.

The resilience studies aim to provide an overview of the overall function of the system, including qualitative system dynamics and vulnerability analysis. The starting point is to build and refine expert understanding of systems from the data and literature, then the next step is to enter new input from experts so that local perceptions will be captured in the existing data (Miller et al, 2010).

Folke (2006) suggests that the characteristic of resilience from a socio-ecological perspective is that there is interplay of disturbances, reorganization, mutual support, and development. Meanwhile, the focus of attention is on adaptive capacity, transformability, learning, and innovation. Currently the food system is intrinsically more complex considering that it includes many different processes, value chains, actors, and interactions between elements in the food system.

The outcomes of the food system affect multiple stakeholders and sectors and sometimes lead to conflicts. This condition then creates a lot of uncertainty and complexity for the food security of a society. These various challenges in the food system then cause the need to think about resilience in the food system so that it does not have an impact on people's lives. Resilience thinking has a very big possibility to contribute to food security and sustainable food systems (Tendall, 2015).

\section{Framework of thinking}

The concept of food resilience has actually been used by the world food and agriculture organization (FAO) in advocating for the development of food system resilience in various contexts (Tendall et al, 2015). Food resilience can be seen at various stages of the food system, starting from the individual stage to national and global levels, which signals that the food system is more participatory in nature, explicitly adopting general system mechanisms. Functionally, the special purpose of the food system is to produce undesirable outcomes such as food and nutrition insecurity and environmental degradation, so that resilience will ensure the sustainability of the food security system.

The aim of the food system is to ensure the adequacy, accuracy and access of food for all. Adequacy is understood as the adequacy of the quantity and quality of food and nutrition; accuracy means cultural, technical, and nutritional accuracy. Accessibility means physical and economic access. The three dimensions that have been discussed are elements of the concept of food security, meanwhile, with regard to resilience, the dimension of stability is still added. During the disturbance period, the dimension of stability is needed.

As stated by Alinovi (2008), food resilience is limited to the ability of the system to overcome the drivers of change, internal or external disturbances, cyclical or structural, sudden or gradual originating from natural, political, social and economic factors.

The food resilience and food security have different meanings, resilience places more emphasis on the sustainability of the food system to continue to carry out its functions properly. The reciprocal relationship between food resilience and sustainability lies in the ability of the food system to face shocks at any time, while food 
sustainability is the ability to sustain the system in the long term. Therefore sustainability is emphasized as the capacity to achieve today's goals without jeopardizing the capacity in the future (Brown et al, 1987)

In the context of assessing the resilience of community food security systems towards food security sustainability, the authors use the Twin Track approach (FAO, 2004). The twin track approach is a conceptual and operational analysis approach, which includes two paths, namely; (1) the rural livelihood improvement measures; (2) provide support quickly to food vurnerable groups (Pingali, 2005). These two pathways reinforce and interact with each other, which then results in incentives towards a stable community food security. As an illustration of this frame of mind, the following authors present a schematic of a framework.

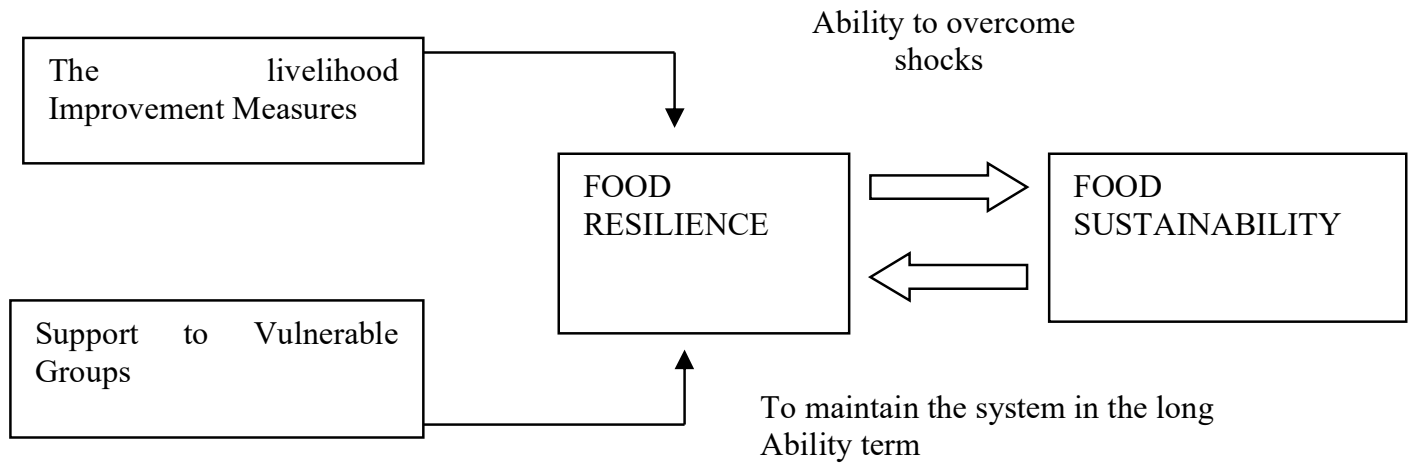

The Schema Framework of thought: Adopted from Tenuan eı al ( $\angle$ U $J)$ allu г AU ( $\left.\angle U V^{4}\right)$

\section{Research Methods}

This research uses case studies, in accordance with the research objectives which will explore various matters related to food resilience in the aspects of availability, access and utilization, as well as stability in local communities in Timor Tengah Selatan regency. The case study design uses the mix method approach (Creswell, 1994., Neuman, 2003).

The qualitative approach, researchers can understand what, how, and why something happens in the life of the community being studied. Researchers use this design because it explains empirical facts found in the field. Whereas with the quantitative approach, we want to see how the rating scale is after going through the frequency distribution process in understanding resilience at the availability, access and utilization stages, and the stability stage.

The variable in this study is a single variable, namely food resilience. Variables of food resilience in Timor Tengah Selatan district include; resilience in aspects of food availability, resilience in aspects of access and utilization of food, and resilience in aspects of food stability.

The population of this study is the entire unit of analysis of the study, namely; households (haousehold) of people affected by food shortages in rural areas in Timor Tengah Selatan regency, food security policy administrators including staff at the Food Security Agency, officials at the District office, officers at the village office, traditional leaders, and stakeholders. Determination of the sample is carried out in a cluster, both the apparatus cluster, the sub-district cluster and the affected household cluster, so the number obtained is 98 informants.

The technique used is a survey using a data collection tool in the form of a questionnaire with answers that have been categorized in numerical form, following a Likert scale. There are two types of data collected in this study, namely quantitative data and qualitative data. Data sources for quantitative data were obtained through research respondents, while for qualitative data through key informants using the following techniques; observation, interview, questionnaire, and documentation.

This study uses mix methods of analysis and interpretation of data by prioritizing qualitative methods (dominant-less dominant design, Creswell: 1994). Quantitative data in the form of frequency tables and analysis of the results of their categorization forms the basis of analysis and interpretation.

\section{The status of Food Security in Timor Tengah Selatan Regency}

\section{a. Food vulnerability}

The composite map explains the conditions of vulnerability to food insecurity in an area (sub-district) caused by a combination of various dimensions of food insecurity. The based on the weighted results, the 
villages are grouped into 6 priorities. Priority 1 is the main priority that describes the highest level of vulnerability, while priority 6 is a priority that is relatively more food resilient. In other words, priority 1 areas (villages) have a greater level of risk of vulnerability to food insecurity than other areas (villages) and thus require immediate attention. The even so, the area (village) that is in priority 1 does not mean all of the population is in a food insecure condition, on the other hand, the area (village) which is in priority 6 does not mean that all of the population is food resistant.

The based on the results of this analysis, of the 278 villages / wards in Timor Tengah Selatan Regency, there were 7 villages (Priority 1), 20 villages (Priority 2), 57 villages (Priority 3), 79 villages (Priority 4), 68 villages (Priority 5) and 47 villages (Priority 6).

\section{b. Food Production}

The agricultural sector (including livestock, forestry and fisheries) has contributed $44.45 \%$ of the Gross Regional Domestic Product (GRDP) of Timor Tengah Selatan Regency in 2018 and provides significant opportunities to contribute to improving food security, poverty alleviation, and the dynamics of economic growth. The Rice and maize are the staple ingredients in Timor Tengah Selatan Regency which account for nearly $50.4 \%$ of the regency total cereal production. The tuber production in Timor Tengah Selatan District has decreased in 2016 and 2018. This decline is mainly due to a lack of expansion of the planted area. Rice production increased $54.88 \%$ over 5 years, from achieving production of 10,889 tonnes in 2014 to 33,883 in 2018.

Table 2. Production of Main Cereals and Tubers 2014-2018 (Tons)

\begin{tabular}{|l|r|r|r|r|r|r|}
\hline \multicolumn{1}{|c|}{ Cereals } & \multicolumn{1}{c|}{2014} & \multicolumn{1}{c|}{2015} & \multicolumn{1}{c|}{2016} & \multicolumn{1}{c|}{2017} & \multicolumn{1}{c|}{2018} & \multicolumn{1}{c|}{$\begin{array}{c}\text { Average 5 } \\
\text { years }\end{array}$} \\
\hline Rice & 10.889 & 16.811 & 26.310 & 27.640 & 33.883 & 23.106 \\
maize & 159.463 & 201.320 & 211.644 & 178.647 & 223.152 & 194.845 \\
Cassava & 38.345 & 39.360 & 23.320 & 59.165 & 36.360 & 39.310 \\
Sweet potato & 1.004 & 1.436 & 6.356 & 6.448 & 1.928 & 3.434 \\
& & & & & & 260.695 \\
\hline Total & 209.701 & 258.927 & 267.63 & 271.9 & 295.323 & 263 \\
\hline
\end{tabular}

Source: Regency in Figures 2014-2018, BPS

In 2018 , the total production of cereals and tubers reached 295,323 tons, 33,883 tons of rice, 223,152 tons of corn, 36,360 tons of cassava and 1,928 tons of sweet potato.

\section{c. Food Production Growth}

The total cereal production and production growth rate in 2014-2018 showed a growth of $66.27 \%$. Total rice production in 2014 was 10,889 tons to 33,883 tons in 2018 and total maize production in 2014 was 159,463 tons to 223,152 tons in 2018 .

Table 3. Total Cereal Production per Year and Growth Rate Production (2014-2018)

\begin{tabular}{|c|c|c|c|c|c|c|}
\hline \multirow{2}{*}{ Sub-District } & \multicolumn{5}{|c|}{ Total Cereal Production } & \multirow{2}{*}{$\begin{array}{l}\text { Growth } \\
\text { Rate } 2014 \\
-2018 \\
\end{array}$} \\
\hline & 2014 & 2015 & 2016 & 2017 & 2018 & \\
\hline Mollo Utara & 11571 & 12527 & 14106 & 7901 & 12379 & 22.22 \\
\hline Fatumnasi & 1035 & 1562 & 2685 & 870 & 950 & 23.71 \\
\hline Tobu & 1786 & 1559 & 5985 & 4648 & 5853 & 32.08 \\
\hline Nunbena & 2068 & 3124 & 4793 & 4081 & 4985 & 24.72 \\
\hline Mollo Selatan & 4445 & 8341 & 9544 & 5350 & 10170 & 24.84 \\
\hline Polen & 6541 & 7546 & 7246 & 7019 & 8299 & 21.62 \\
\hline Mollo Barat & 4102 & 5174 & 4261 & 5790 & 15165 & 29.58 \\
\hline Mollo Tengah & 2706 & 4062 & 4513 & 2714 & 3360 & 21.96 \\
\hline
\end{tabular}




\begin{tabular}{|l|r|r|r|r|r|r|}
\hline Kota SoE & 162 & 840 & 1845 & 1650 & 1809 & 54.37 \\
\hline Amanuban Barat & 9859 & 9988 & 10947 & 9385 & 11377 & 21.50 \\
\hline Batuputih & 7413 & 4970 & 6745 & 6567 & 8602 & 22.63 \\
\hline Kuatnana & 9206 & 9392 & 9986 & 8380 & 10043 & 21.36 \\
\hline Amanuban Selatan & 10032 & 16090 & 19846 & 22685 & 29834 & 25.90 \\
\hline Noebeba & 3400 & 8447 & 14907 & 3635 & 5952 & 28.65 \\
\hline Kuanfatu & 10988 & 11659 & 11509 & 17074 & 7978 & 20.56 \\
\hline Kualin & 5282 & 8565 & 9312 & 5434 & 7192 & 22.38 \\
\hline Amanuban Tengah & 3080 & 3085 & 4203 & 5133 & 6765 & 24.74 \\
\hline Kolbano & 13857 & 8811 & 745 & 2739 & 6386 & 62.61 \\
\hline Oenino & 5994 & 5974 & 7490 & 7745 & 7245 & 21.51 \\
\hline Amanuban Timur & 8581 & 12849 & 11032 & 7316 & 11052 & 22.35 \\
\hline Fautmolo & 314 & 4785 & 2715 & 2736 & 5697 & 67.63 \\
\hline Fatukopa & 4616 & 5224 & 5286 & 5775 & 5756 & 21.46 \\
\hline KiE & 12687 & 12686 & 16846 & 14194 & 13854 & 21.21 \\
\hline Kot'olin & 5716 & 6455 & 6666 & 4555 & 6847 & 22.03 \\
\hline Amanatun Selatan & 308 & 9568 & 10140 & 11076 & 11520 & 15.159 \\
\hline Boking & 6619 & 7252 & 3960 & 4047 & 5115 & 22.34 \\
\hline Nunkolo & 5620 & 5620 & 5574 & 8607 & 8379 & 22.83 \\
\hline Noebana & 266 & 840 & 1770 & 3775 & 3048 & 56.69 \\
\hline Santian & 652 & 4040 & 2280 & 1671 & 7578 & 46.14 \\
\hline Amanatun Utara & 9027 & 6375 & 4647 & 10410 & 24.18 \\
\hline Toianas & 605 & 12393 & 6894 & 423 & 62.64 \\
\hline Kokbaun & 6160 & 2307 & 2337 & 3012 & 82.87 \\
\hline \multicolumn{1}{|c|}{ Jumlah } & 170.952 & 216.827 & 238.012 & 206.430 & 257.035 & \\
\hline Regency in Figur & & & & & \\
\hline
\end{tabular}

Source: Regency in Figures 2014-2018, BPS

\section{Description of Food Resilience in Timor Tengah Selatan Regency}

Food resilience in this study includes; (a) resilience of food availability through efforts to increase production, availability and handling of food insecurity; resilience of access and utilization of food through stabilizing food distribution and reserves, as well; (c) resilience to food stability by increasing the quality of consumption and food safety. Food resilience policy is directed at encouraging the creation of conducive social, cultural and economic conditions, towards food resilience and sustainable food security.

\section{a. Resilience of Food Availability.}

The food availability is the condition of the availability of food from production, food reserves and food intake. Regarding resilience, food availability can be seen in table 4.

Table 4. Resilience Indicators of Food Availability

\begin{tabular}{|c|l|c|c|}
\hline NO & \multicolumn{1}{|c|}{ INDICATORS } & SCORE & $\begin{array}{c}\text { CLASSIFICATIO } \\
\text { N }\end{array}$ \\
\hline 1 & Food supply to the most vulnerable groups & 411 & Good \\
2 & Rural food production from small farmers & 389 & Good \\
3 & Investments in rural infrastructure & 310 & Enough \\
4 & Revitalization of the rural livestock sector & 243 & poorly \\
5 & Rehabilitation and conservation of natural resources & 326 & Enough \\
6 & Increased income \& other rights for the community & 325 & Enough \\
7 & Food aid & 318 & Enough \\
8 & Seed aid & 301 & Enough \\
\hline & Average & 340,38 & Good \\
\hline
\end{tabular}

Source: Processed Data, 2020 
In general, the resilience of food availability in TTS district is in a good classification, but there are several indicators that still need to be improved so that the resilience gets better, namely indicators on the revitalization of the livestock sector, food aid and seed assistance. Resilience availability, the most prominent is the indicator of food supply in vulnerable groups, which are in the good category.

The results of the interviews with the respondents indicated that the food supply to vulnerable groups was indeed running smoothly considering that the local government has a food assistance program for vulnerable groups. The program is called Business Assistance for the purple sweet potato cultivation group as an activity to accelerate the increase in production, productivity and quality of food crops, especially purple sweet potato.

The purpose of the activities of the purple sweet potato cultivation group business assistance is; (a) ensure the correct application of purple sweet potato production technology in the cultivation location area by increasing farmers' knowledge and skills; (b) foster member cooperation in realizing the functions of farmer groups; (c) accelerating the increase in sweet potato production; (d) availability of purple sweet potato to improve the quality of local food-based consumption.

\section{b. Resilience of Food Access and utilization}

Access to food is the ability of a household to obtain sufficient nutritious food, through one or a combination of various sources such as; own production and supply, purchases, bartering, gifts, loans and food aid. Food may be readily available in an area but inaccessible to certain households if they are physically, economically or socially unable to access adequate amounts and diversity of food.

Food use refers to the use of food by households and the ability of individuals to absorb and metabolize nutrients. Food utilization also includes ways of storing, processing and preparing food, water safety for drinking and cooking, hygiene conditions, feeding habits, especially for individuals with special food needs, food distribution in households according to individual needs (growth, pregnancy and breastfeeding), and the health status of each household member. The following table 5 is a description of the resilience of access to and use of food.

Table 5. Resilience Indicators of Food Access and Utilization

\begin{tabular}{|c|l|c|c|}
\hline NO & \multicolumn{1}{|c|}{ INDICATORS } & SCORE & CLASSIFICATION \\
\hline 1 & Re-establishment of rural institutions & 330 & Good \\
2 & Access to rural assets & 337 & Good \\
3 & Guaranteed access to land & 259 & Enough \\
4 & Reviving the rural financing system & 252 & Poorly \\
5 & Strengthening the labor market & 359 & Enough \\
6 & Food safety assurance mechanisms & 353 & Poorly \\
7 & Social rehabilitation program & 258 & Enough \\
8 & Asset redistribution & 250 & Poorly \\
9 & Cash transfer and or food transfer & 259 & Enough \\
10 & Social relief program & 336 & Good \\
11 & Nutrition intervention program & 257 & Enough \\
\hline & Everage & 277,27 & Enough \\
\hline
\end{tabular}

Source: Processed Data, 2020

The based on table 5, it shows that the resilience of access and utilization in TTS district is in a sufficient classification. The measurement results show that of the 11 indicators of resilience measurement, there are 3 indicators that show poor classification, namely; (a) indicators of reviving the rural financing system; (b) food safety guarantee mechanisms; and (c) asset redistribution. The results of the interviews also reinforce these findings which state that the resilience of food access still needs to be optimized.

\section{c. Food Stability Resilience}

The food stability includes availability, access and utilization, so that food stability is a state of sustainable food. A sustainable food system is a food system that provides food security and nutrition for all that is based on the economy, social and environment to produce food security and nutrition for future generations and 
does not endanger it. The conditions regarding the resilience of sustainable food stability in TTS district can be seen in table 6 .

Table 6. Food Resilience Stability Indicators

\begin{tabular}{|c|c|c|c|}
\hline NO & INDICIATORS & SCORE & $\begin{array}{c}\text { CLASSIFICATI } \\
\text { ON }\end{array}$ \\
\hline 1 & Diversification of agriculture and employment & 271 & Enough \\
\hline 2 & food safety and vulnerability monitoring & 370 & Good \\
\hline 3 & Structural food insecurity & 411 & Good \\
\hline 4 & Develop risk management & 250 & Poorly \\
\hline 5 & Revive access to credit systems and savings & 327 & Enough \\
\hline 6 & mechanisms & 376 & Good \\
\hline 7 & $\begin{array}{l}\text { Rebuilding social safety nets } \\
\text { Efforts to build peace }\end{array}$ & 418 & Good \\
\hline & Average & 360,43 & Good \\
\hline
\end{tabular}

Source: Processed Data, 2020

The based on table 6 , it is known that the food stability resilience condition in TTS regency is in a good classification, but there are still indicators of resilience stability that still show unfavorable conditions, developing risk management, reviving access to credit systems and savings mechanisms.

Discussion

The based on the research data, it is known that the food resilience in TTS regency shows a good category. These results were obtained after combining 3 dimensions of food security

The food resilience of TTS district is said to be good on the grounds that the food system remains stable even though this area is categorized as vulnerable to food insecurity. According to Pingali (2005) a food system that has resilence if the system remains stable and continues to adapt without experiencing major changes in its basic function. There is also the risk of a decline in the functioning and provision of services when the system is under high pressure and the public is affected by a weakening of the public sector and loss of market structure. The following is an analysis of aspects of food resilience.

\section{a. Resilience of Food Availability}

The data on the resilience of food availability shows a good classification, this fact is supported by data that the food supply in TTS regency is experiencing sufficient growth, namely $66.27 \%$.

The achievement of food supply growth is also inseparable from the strategies taken to maintain food availability, namely; (a) increased productivity; (b) land expansion; (c) Reduction of climate-related risks; and (d) Strengthening of institutions for farmers.

Resilience of food supply shows the capacity of the food system to withstand changes, determines the persistence of relationships in a system and is a measure of the system's ability to absorb variable changes, moving the driving variables. Ability to understand systems in support of adaptation, community and economic maintenance and responses to how they solve problems (Thomas et al, 2007)

\section{b. Resilience of Food Access and Utilization}

The access to food is the ability of a household to obtain enough food, whether it comes from its own production, stocks, purchases, bartering, gifts, loans and food assistance. The food may be available in an area but cannot be accessed by certain households due to limited: (1) economic access: financial capacity to buy sufficient and nutritious food; (2) physical access: the existence of infrastructure to reach food sources; and / or (3) social access: social capital that can be used to obtain informal support in accessing food, such as barter, loans or social safety net programs.

The food use refers to the use of food by households and the ability of individuals to absorb and metabolize nutrients. The use of food also includes storage, processing and preparation of food, water safety for drinking and cooking, hygiene conditions, feeding habits (especially for individuals with special dietary needs), food distribution in the household according to individual needs (growth, pregnancy and breastfeeding), and the health status of each household member.

Access to and use of food is closely related to the high poverty rate in TTS regency. The various poverty reduction programs have been carried out by the Timor Tengah Selatan Regency government, this 
effort has resulted in a reduced poverty ratio, namely from $29.44 \%$ ( 545,800 people / 136,450 families) in 2017 to $28.06 \%(522,520$ people / 130,630) in 2018 .

At the village level, based on data from the poverty management program in 2018 , there are 42 villages that have the ratio of households with the lowest welfare level above $15.10 \%$ which is in priority 1 . A total of 42 villages $(15.10 \%)$ are included in priority 2 , and 55 villages (19.78\%) are in priority 3 . In the future, poverty reduction programs must be improved and prioritized in these 139 villages.

The regard to access, the strategies adopted are; (a) handling food insecure areas; (b) utilization of yards for food development; c) monitoring and analysis of community food access; (d) development of independent Food villages; (e) development of village food barns; (f) increasing food diversification through local food development, including including; increasing diversification of balanced nutrition food consumption; supplementary feeding for toddlers; diversification of farming and local food development. Meanwhile, with regard to food utilization, the strategy is to improve the nutritional status and health of vulnerable groups.

The research data on the resilience of access to and use of food are in the adequate classification, this condition is caused by the indicators of resilience of access to food that are not yet maximal, namely; (a) indicators of reviving the rural financing system; (b) food safety guarantee mechanisms; and (c) asset redistribution. According to the version of the Resilience Alliance (2009), access and utilization resilience occurs because of the system's ability to absorb shocks and cross a threshold so that it can regenerate after a disturbance. The disturbance in question is the level of poverty, so it is hoped that the role of institutions, social capital, leadership, and learning.

This context shows that there has been an expansion of the concept of resilience, especially with regard to socio-ecological systems, resulting in tensions between the pressure on the system, namely the current state and the transformation to a new system condition. The way food resilience works can be seen when the food system responds to social conditions amid climate change. According to Adger (2000) social resilience is the ability of a group or community to cope with external pressures and disturbances as a result of social, political and environmental changes.

\section{c. Food Stability Resilience}

The food stability is stability in availability, access and utilization. Stability is influenced by a number of factors such as political instability, weather conditions, and economic factors that impact food security.

The stability indicates a steady state, even sustainable. A sustainable food system is a food system that provides food security and nutrition for all that is based on the economy, social and environment to produce food security and nutrition for future generations and does not endanger it.

The results of the resilience stability study measure food stability based on indicators; (a) diversification of agriculture and employment; (b) food security and vulnerability monitoring; (c) structural food insecurity; (d) develop risk management; (e) reviving access to credit systems and savings mechanisms; (f) rebuilding social safety nets; (g) efforts to build peace. The resilience stability is in a good classification, but what needs attention is the risk management development indicator.

The results of interviews with respondents indicated that the development of risk management was not given much attention in the food security program carried out by local governments. It is evident from the data that food vulnerability is still very large. Vulnerability refers to vulnerability to food and nutrition insecurity. The level of vulnerability of an individual, household or community group is determined by an understanding of risk factors and the ability to cope with stressful situations. According to Gallopin (2006), vulnerability is a form of disruption to the system, which is disturbed by the food system, so that sustainable food is not achieved.

The food insecurity can be a chronic or transient condition, chronic food insecurity is the long-term inability to meet minimum food requirements and is usually associated with structural and factors that do not change rapidly, such as the local climate, land types, local government systems, public infrastructure, land ownership systems, income and livelihood distribution, inter-ethnic relations, education level, socio-culture / customs, and others.

Meanwhile, transient food insecurity is a temporary, short-term inability to meet minimum food needs, mostly related to dynamic factors that can change rapidly / suddenly such as infectious diseases, natural disasters, displacement, changes in market function, debt levels and migration.

\section{Conclusion}

The resilience is the capacity of the food system to cope with shocks and maintain system function, as well as the capacity to renew, reorganize and develop a food system. The resilience that occurs in the food system in Timor Tengah Selatan district shows the results are less focused on achieving a sustainable food system. 
The based on an analysis of food resilience in Timor Tengah Selatan district using the Twin Track approach (FAO, 2004), an approach that emphasizes conceptual and operational analysis, through (1) measures to improve rural livelihoods; (2) providing rapid support to food vurnerable groups, it is concluded:

\section{a. Resilience of Food Availability}

The based on the research data, it shows that the availability resilience shows good category / classification, there are indicators that are quite significant so that an increase in the value of the availability resilience score can be achieved, namely food supply to vulnerable groups and rural food production has increased. The fact, other indicators show adequate classification, and there is even a lack of evaluation on the indicators for the revitalization of the rural livestock sector.

\section{b. The Resilience of Food Access and Utilization}

The results showed that the access and use of food were in the adequate classification. Access to food is economic, physical, and social access. Meanwhile, food use includes storage, processing and preparation of food, water safety for drinking and cooking, hygiene conditions, feeding habits (especially for individuals with special food needs). Resilience has not been maximized because there are a number of indicators that need great attention so that the resilience of access to and use of food can be increased, namely (a) guaranteed access to land, (b) reviving the rural financing system; (c) strengthening the labor market; (d) Social rehabilitation program; (e) asset redistribution, and; (f) nutrition intervention program.

\section{c. Food Stability Resilience}

The food stability in Timor Tengah Selatan regency is good classification, indicated by the results of measurement of resilience indicators which show stability in supply, access and utilization, although there are still indicators that need serious handling such as; diversification of agriculture and rural employment, the development of risk management, and the need to revive access to credit systems and savings mechanisms.

\section{Recommendation}

The based research results, it shows that there are still indicators of resilience that need attention from all food stakeholders in South Central Timor district, so it is suggested:

a. It is necessary to revitalize the rural livestock sector. Empirical conditions do show that in the last few decades the rural livestock sector has experienced a decline in productivity. Various reasons so that this happens, namely; the livestock sector is experiencing degradation due to climate change which affects the area of grazing fields; rural livestock sector policies have undergone many changes; incentives to increase livestock productivity are diverted to other sectors such as the provision of rural facilities and infrastructure and food assistance.

b. It is necessary to revive the local-based rural financing system. The current rural financing system is dominated by modern systems such as the banking system, pawnshop system, cooperative systems which are managed in a modern way. The old system with the pattern of local wisdom has been abandoned, rural communities have been influenced by materialistic values. One example of a local system that needs to be turned on is the culture of "drinking hot water". This system is the cultural value of mutual cooperation for community financing.

c. It is necessary to develop risk management so that all rural communities in Timor Tengah Selatan district have an understanding of risk factors and the ability to overcome stressful situations for all people and food stakeholders in this area. The risk factors in question are developing an understanding of the factors causing food insecurity, how to overcome them, providing an understanding of groups that are vulnerable to food insecurity.

\section{References}

Adger, W.N., 2000. Social and ecological resilience: are they related? Progress in Human Geography 24 (3), $347-$ 364.

Alinovi,L Hemrich, G., Russo, L., 2008. Beyond Relief-food Security in Protracted Crises. Food and Agriculture Organization of the United Nations, Rugby, UK, p. 274.

American Dietetic Association. (2007). Healthy land, healthy people. Building a better understanding of sustainable food systems for food and nutrition professionals. A primer on sustainable food systemsand emerging roles for food and nutrition professionals. Chicago, IL: American Dietetic Association.

Badan Ketahanan Pangan \& Penyuluhan Kabupaten TTS, 2018, Laporan, Akuntabilitas Kinerja (LAKIP)

Brklacich, M., Bryant, C. R., \& Smit, B. (1991). Review and appraisal of concept of sustainable food production systems. Environmental Management, 15(1), 1-14. https://doi.org/10.1007/BF02393834

Brown,B.J., Hanson,M.E., Liverman, D.M., Merideth, R.W.,1987. Global sustainability: toward definition. Environ.Manag.11(6),713-719. 
Carpenter, S.R., Gunderson, L.H., 2001. Coping with collapse: ecological and social dynamics in ecosystem management. BioScience 51, 451-457.

Creswell, J.W. 1994. Research Design Qualitative and Quantitative Approach. UK-New Delhi-California : SagePublication.

Dreze, Jean and Amartya Sen,1989. Hunger and Public Action, Oxford:Clarendon Press.

El Bilali, Hamid, Carolin Callenius, Carola Strassner, Lorenz Probst.,2018., Food and nutrition security and sustainability transitions in food systems, Food and Energy Security https://doi.org/10.1002/fes3.154

FAO, SOFI (2004) The State of Food Insecurity in the World, 2004: Factoring the resilience of food systems and communities into the response to protracted crises. FAO, Rome.

Folke, Carl.,2006, Resilience: The emergence of a perspective for social-ecological systems analyses, Global Environmental Change 16 (2006) 253-267

Garnett, T. (2014). Three perspectives on sustainable food security: Efficiency, demand restraint, food system transformation. What role for life cycle assessment? Journal of Cleaner Production, 73, 10-18. https://doi.org/10.1016/i.jclepro.2013.07.045

Gallopin, Gilberto C, 2006, Lingkages Between Vurnerability, Resilience, and Adaptive Capacity, Global Environmental Change 16 (2006) 293-303. doi:10.1016/j.gloenvcha.2006.02.004

HLPE. (2014a). Food losses and waste in the context of sustainable food systems. A report by the High Level Panel of Experts on Food Security and Nutrition (HLPE) of the Committee on world food security. Retrieved from http://www.fao.org/3/a-i3901e.pdf

Holling, C.S., 2001. Understanding the complexity of economic, ecological, and social systems. Ecosystems 4, 390-405.

Halberg, Niels, and Adrian Muller, eds. 2013. Organic Agriculture for Sustainable Livelihoods. London: Routledge.

Janssen, M. A., and E. Ostrom. 2006. Resilience, vulnerability, and adaptation: a cross-cutting theme of the International Human Dimensions Programme on Global Environmental Change. Global Environmental Change 16(3):237-239.

Johnston, J. L., Fanzo, J. C., \& Cogill, B. (2014). Understanding sustainable diets: a descriptive analysis of the determinants and processes that influence diets and their impact on health, food security, and environmental sustainability. Advances in Nutrition, 5(4), 418-429. https://doi.org/10.3945/an.113.005553

Lassa, Jonatan, 2009. Diskursus Kelaparan dan Ketahanan Pangan Indonesia 1958-2008: Studi Kasus Nusa Tenggara Timur, dalam 50 Tahun Ziarah Pangan Nusa Tenggara Timur Jonatan Lassa, Dion DB Putra, Tony Kleden (Editor), Kupang: PT Timor Media Grafika

Maxwell, Daniel G,1996. Measuring food insecurity: the Frequency and Severity of Coping Strategies, Food Policy, 21 (2):291-304.

Miles, Matthew B and A Michael Huberman.,1994, Qualitative Data Analysis, 2nd ed, Sage: London.

Miller, Fiona., 2010 Henny Osbahr, Emily Boyd, Frank Thomalla, Sukaina Bharwani,Gina Ziervogel, Brian Walker, Jörn Birkmann, Sander van der Leeuw, Johan Rockström,Jochen Hinkel, Tom Downing, Carl Folke and Donald Nelson, Resilience and Vulnerability Complementary or Conflicting Concepts?, Ecology and Society, Vol. 15, No. 3

Mueller, D.J. 1986. Measuring Social Attitudes. New York-London: Teacher College Press.

Neuman, W.Lawrence.,2003, Social Research, Methods: Qualitative and Quantitative Approach, University of Wisconsi: Boston New York

Nursalam, 2019., The Local Food Security System in Regency of Timor Tengah Selatan (TTS), Prosiding International Conference On Governance Innovations And Social Sciences (ICOGISS) 2019, ISBN: 978-602-6988-75-1

Ofong,Lexand, 2007., Menuju Ketahanan Pangan Berkelanjutan Di NTT (Towards Food Security in NTT), Working Paper, Institute of Indonesia Tenggara Studies

Pakpahan, Agus dan Effendi Pasandaran. (1990). Keamanan Pangan: Tantangan dan Peluangnya, Dalam Prisma No. 2 Tahun XIX, Jakarta: LP3ES. Program Pembangunan Daerah NTT, Tahun 2004-2008.

Pingali, Prabhu, Luca Alinovi and Jacky Sutton, 2005, Food security in complex emergencies: enhancing food system resilience, Disasters, 2005, 29(s1)

Quinlan, Allyson E, Marta Berbes-Blazquez, L. Jamila Haider and Garry D. Peterson.,2016, Measuring and assessing resilience: broadening understanding through multiple disciplinary perspectives, Journal of Applied Ecology 2016, 53, 677-687

Resilience Alliance, 2009. Assessing and managing resilience in social-ecological systems: a practitioner's workbook, Version 1.0. [online] URL: http://wiki.resalliance.org/index.php/Main Page

Ramos-Martin, J. 2003. Empiricism in ecological economics: a perspective from complex systems theory. Ecological Economics 46(3):387-398 
Reuter, Thomas., Culture, Agriculture, Food and Environment ISSN 2153-9553, reserved. DOI: 10.1111/cuag. 12135

Strauss, A., and Corbin,J.,1991, Basics of Qualitative Research: Grounded Theory Procedures and Technique, Newbury Park, CA: Sage.

Tata Ngomea, Precilia I, Charlie Shackletonb, Ann Degrandec, Eric Joel Nossia, Francis Ngomea.,2019, Assessing household food insecurity experience in the context of deforestation in Cameroon, Food Policy 84 (2019) 57-65

Tendall, D.M.,2015., J.Joerin, B.Kopainsky, P.Edwards, A.Shreck, Q.B.Le, P.Kruetli, M. Grant, J.Six, Food system resilience: Defining the concept, Global Food Security 6 (2015)17-23

Thomas, D. S. G., C. Twyman, H. Osbahr, and B. Hewitson. 2007. Adapting to climate change and variability in southern Africa: farmer responses to intra-seasonal precipitation trends. Climatic Change 83:301-322.

Timmer, C Peter, 2005, Food Security and Economic Growth: an Asian Perspective, dalam Asian Pacific Economic Literature, 19 (1): 2-3.

Umar, Husain,. 2003. Metode Riset Perilaku Konsumen Jasa, Jakarta: Ghalia Indonesia.

Yamane, T, 1967., Elementary Sampling Theory, New Jersey, Prentice-Hall Inc 